\title{
Polyphasic Analysis of Pectinolytic and Stress-Resistant Yeast Strains Isolated From Ivorian Cocoa Fermentation
}

\author{
Lamine Samagaci ${ }^{1}$, Honoré G. Ouattara ${ }^{1}$, Bernadette G. Goualié ${ }^{1} \&$ Sébastien L. Niamke ${ }^{1}$ \\ ${ }^{1}$ Laboratoire de Biotechnologies, UFR Biosciences, Université Félix Houphouët-Boigny Abidjan, Côte d'Ivoire \\ Correspondence: Honoré G. Ouattara, Laboratoire de Biotechnologies, UFR Biosciences, Université Félix \\ Houphouët-Boigny, Abidjan, Côte d'Ivoire. Tel: 225-2244-4473. E-mail: kidou12@yahoo.fr
}

Received: September 15, 2014 Accepted: November 20, 2014 Online Published: December 7, 2014

doi:10.5539/jfr.v4n1p124

URL: http://dx.doi.org/10.5539/jfr.v4n1p124

\begin{abstract}
Microbial preparation containing pectinolytic strains as starter culture should help to standardize cocoa fermentation and reduce the lost due to the variability of cocoa bean. In this study, carbon metabolism, fermentative capacity and effect of environmental conditions on pectinase synthesis were analyzed in four yeast strains previously characterized as highly pectinolytic and stress resistant. The strains showed a restricted carbon metabolism profile with capacity to ferment only glucose and fructose and grown maximally at $5 \%$ of these carbon sources. Furthermore, yeasts strains were able to keep round $80 \%$ of their relative growth at up to $15 \%$ of sugar concentrations and proved to be osmotolerant at $25 \%$ glucose. Theses strains expressed their highest fermentative capacity at $35{ }^{\circ} \mathrm{C}$ producing up to $10.78 \mathrm{~cm}^{3}$ of $\mathrm{CO}_{2}$ and lost more than $50 \%$ of this capacity at $40{ }^{\circ} \mathrm{C}$. The isolates studied produced polygacturonase as sole pectinase, optimal production of this enzyme is reached at $\mathrm{pH}(5-6)$, at incubation temperature of $30^{\circ} \mathrm{C}$ for strains YS 128 , YS 202 and $35^{\circ} \mathrm{C}$ for strains YS 165 and YS 201. However, stress conditions such as $0.5 \%$ acetic acid, $2 \%$ lactic acid, $6 \%$ citric acid and $6 \%$ ethanol repress strongly polygalacturonase production in the strains analyzed. Yeast strains studied present some physiological properties potentially useful for cocoa fermentation but the use of these strains as starter should take into account, the stress conditions susceptible to hinder pectinase production.
\end{abstract}

Keywords: cocoa fermentation, polygalacturonase production, stress condition, starter, yeasts growth

\section{Introduction}

Cocoa beans (Theobroma cocoa) constitute the main raw material for chocolate industries. However, cocoa beans need to be fermented and dried before its technological transformation into chocolate. Fermentation is essential for development of specific aroma, flavor and color of chocolate (Leal et al., 2008). Yet, cocoa fermentation is essentially led by microbial flora including yeasts, lactic acid bacteria (LAB), acetic acid bacteria (AAB) and Bacillus. During cocoa fermentation process, yeasts ferment the sugar (glucose, fructose and sucrose) contained in the mucilaginous pulp to produce ethanol that is further oxidized into acetic acid by $\mathrm{AAB}$, allowing an increase of temperature in fermenting mass. Moreover, the penetration of acetic acid into beans and the decrease of inner $\mathrm{pH}$, subsequently activates in the cotyledons, the proteolytic enzymes that are responsible for final quality of the fermented beans and chocolate (Forsyth \& Quesnel, 1963; Ziegleder, 1991; Holm et al., 1993; Biehl \& Voigt, 1996; Schawn et al., 1997; Ouattara et al., 2008).

Among the microbial flora involved in cocoa fermentation, yeasts remain very important since they initiate and trigger the biochemical process of fermentation (Ho et al., 2012). In addition to their fermentative activity, another crucial role of yeasts in this process is pectinolytic enzymes production responsible for the breakdown of the pulp (Bhumibhamon \& Jinda, 1997). Pectinolytic enzymes are assumed to have high sensorial impact on the quality of cocoa beans and chocolate (Bhumibhamon \& Jinda 1997; Crafack et al., 2013).

On the other hand, cocoa fermentation is realized by natural and traditional methods, giving variable and non-reproducible quality of fermented and dried cocoa beans (Lopez \& Dimick, 1995; Schwan et al., 1997; Nielsen, 2006). As solution to this problem, the approach presenting the highest potential efficiency is the utilization of microbial preparation as starters. This approach should permit to control and standardize the cocoa fermentation process (Schwan \& Wheals, 2004). 
At date, one of the most interesting targeting properties for microbial starter screening is pectinolytic enzymes. Recently, we have isolated from Ivorian fermenting beans, yeast strains presenting pectinolytic activity and high stress resistance (Samagaci et al., 2014). However, evolution and dynamics of the fermentative environment, lead very often, to stress conditions which are susceptible to impact the production of pectinolytic enzymes and the fermentative capacity of microbial strains during cocoa fermentation.

In this paper we report the influence of various culture conditions related to cocoa fermentation, on the production of pectinolytic enzymes, the growth and the fermentative capacity of yeasts strains isolated from fermenting cocoa beans in Côte d'Ivoire.

\section{Material and Methods}

\subsection{Yeast Strains}

Four yeast strains codified (YS 128, YS 165, YS 201 and YS 202) previously isolated from fermenting cocoa beans have been used in this study. These isolates were screened on solid medium as the best pectinase producers among 205 yeast strains and presented a strong adaptive capacity under cocoa fermentation stress conditions (Samagaci et al., 2014). These isolates where stored at $-80{ }^{\circ} \mathrm{C}$ in MYGP broth supplemented with glycerol 20\% in Eppendorf tubes.

\subsection{Carbon Metabolism and Fermentative Capacity of Yeast Strains}

The carbon metabolism study was carried out by the method described by Wickerham (1951). A preculture was prepared by growing cells in malt extract broth $0.3 \%$ for $24 \mathrm{~h}$ at $30^{\circ} \mathrm{C}$. Then $10 \mu \mathrm{L}$ of the preculture $\left(\mathrm{OD}_{600}=\right.$ 0.5 ) were used to inoculate $10 \mathrm{~mL}$ of sterilized medium contained in $25 \mathrm{~mL}$ tube. This medium, in which a Durham tube was inserted, was composed of $0.5 \%$ yeast extract and $2 \%$ of each carbohydrates tested.The carbohydrates tested were (D-glucose, maltose, D-fructose, sucrose, lactose, D-xylose, D-galactose, Starch, Inositol, Cellobiose, and L-Arabinose). Cultures were incubated at $30{ }^{\circ} \mathrm{C}$ for $48 \mathrm{~h}$ to 3 weeks. The presence of gas in Durham tubes indicates that the isolates ferment carbohydrates with production of $\mathrm{CO}_{2}$.

Yeasts usually oxidize sugars into ethanol with production of gas (Hesclot \& Vladescu, 1994). The volume of gas and ethanol produced is related to fermentative strength of strain (Dung et al., 2012). Fermentative capacity of strains was therefore evaluated by measuring the volume of gas produced from sugars catabolism by a one-step and simple method previously described by Ouattara et al. (2014) with slight modifications. An YPG agar medium containing $0.05 \%$ yeast extract, $0.3 \%$ casein peptone, $5 \%$ glucose or fructose and $1.7 \%$ agar, $\mathrm{pH}$ adjusted to 5 was prepared. Then $1 \mathrm{~mL}$ of the medium was put in a $20 \mathrm{~mL}$ tube and inoculated with $50 \mu \mathrm{L}$ of yeast preculture $\left(\mathrm{OD}_{600}=0.5\right)$, followed by an another layer of $9 \mathrm{~mL}$ to allow anaerobic conditions and gas retention in the tube. The medium was incubated at different temperatures $\left(30,35\right.$ and $40{ }^{\circ} \mathrm{C}$ for $\left.48 \mathrm{~h}\right)$. The volume of gas produced in the tube is given according to the following expression: $V=\pi R^{2} h$ (V: volume of gas produced; R: ray of tube, h: height occupied by the gas produced).

\subsection{Influence of Sugar Concentrations on Microbial Growth}

The influence of sugars on the growth of pectinolytic yeasts was carried out, as described by Osho (2005). The medium used for this study is the Yeast-peptone-dextrose broth ( $0.05 \%$ yeast extract, $0.3 \%$ Casein peptone) supplemented with sugar (glucose or fructose) at different concentrations $(5,10,15,20,25,30,35,40$ and 45\%). The medium is inoculated with $100 \mu \mathrm{L}$ of yeast cells preculture $\left(\mathrm{OD}_{600}=0.5\right)$. The inoculated medium was then incubated at $30^{\circ} \mathrm{C}$ for 5 days and the medium turbidity due to microbial growth was red at $600 \mathrm{~nm}$ against the sterile medium, using a spectrophotometer PIOWAY Medical Lab - UV 752.

\subsection{Pectinases Production in Liquid Medium}

Pectinases production was carried out by the method described by Dzobgefia et al. (2008) with slight modification. A $24 \mathrm{~h}$ preculture of yeast strains $\left(\mathrm{OD}_{600}=0.5\right)$ prepared in malt extract broth was used to inoculate $10 \mathrm{~mL}$ of liquid medium (1\% pectin; $0.28 \%\left(\mathrm{NH}_{4}\right)_{2} \mathrm{SO}_{4} ; 0.1 \% \mathrm{KH}_{2} \mathrm{PO}_{4} ; 0.05 \% \mathrm{MgSO}_{4} .7 \mathrm{H}_{2} \mathrm{O} ; 0.001 \%$ $\mathrm{FeSO}_{4} .7 \mathrm{H}_{2} \mathrm{O} ; 0.6 \% \mathrm{~K}_{2} \mathrm{HPO}_{4}$ and adjusted at $\mathrm{pH}$ ). The medium was incubated at $30{ }^{\circ} \mathrm{C}$ during 5 days. After incubation, the medium was centrifuged at $4500 \times \mathrm{g}$ for $10 \mathrm{~min}$ at $4{ }^{\circ} \mathrm{C}$. The supernatant obtained constitute the crude enzyme extract.

\subsubsection{Pectinolytic Enzymes Assay}

Polygalacturonase activity was assayed by measuring the formation of reducing function of the acid galacturonic from pectin using DNS method (Miller, 1959). The reaction mixture contained $0.5 \%(\mathrm{w} / \mathrm{v})$ orange pectin in 100 $\mathrm{mM}$ sodium phosphate buffer (pH 6) and $0.1 \mathrm{~mL}$ of crude enzyme extract in $0.8 \mathrm{~mL}$ of total volume of reaction mixture. The reaction mixture was then incubated at $40{ }^{\circ} \mathrm{C}$ for $20 \mathrm{~min}$. The blank was prepared in the same 
conditions except that, the crude enzyme were heated at $100{ }^{\circ} \mathrm{C}$ for $20 \mathrm{~min}$ to deactivate enzymatic activity. One unit of enzyme activity $(\mathrm{U})$ was defined as the quantity of acid galacturonic product in micromole per minute. Enzyme production is defined as the number of units of enzyme activity $(\mathrm{U})$ per $\mathrm{mL}$ of supernatant.

Pectin lyase and pectate lyase activities were assayed by measuring the formation of unsaturated galacturonate at $230 \mathrm{~nm}$. For pectin lyase assay, the reaction mixture contained $1 \%(\mathrm{w} / \mathrm{v})$ orange pectin in $100 \mathrm{mM}$ citrate phosphate buffer (pH 6.4), $1 \mathrm{mM}$ EDTA and $0.5 \mathrm{~mL}$ of crude enzymes extract in $1.5 \mathrm{~mL}$ of reaction mixture, while pectate lyase activity was tested by replacing pectin by polygalacturonic acid (pectate) in $75 \mathrm{mM}$ Tris- $\mathrm{HCl}$ buffer ( $\mathrm{pH} 7.5$ ) with $1 \mathrm{mM} \mathrm{CaCl}_{2}$ (Gummadi \& Kumar, 2008). The reaction mixture was incubated at $30^{\circ} \mathrm{C}$ for $20 \mathrm{~min}$. The blanks were also prepared in the same conditions except that, the crude enzymes extract was heated at $100{ }^{\circ} \mathrm{C}$ for $20 \mathrm{~min}$ to deactivate enzymatic activity. One unit of enzyme activity (U) was defined as the quantity of unsaturated product in micromole produced per minute by using a molar coefficient of extinction $\mathrm{e}=$ 5500 (Albersheim, 1966). Enzyme production is defined as the number of units of enzyme activity (U) per mL of supernatant.

The action of pectin methyl esterase on pectin, leads to the release of carboxylic groups which provoke an acidification of the medium. The enzyme activity was assayed by regularly recording the $\mathrm{pH}$ decrease of the medium against a control with pH-meter (HI 2223 Calibration chek pH/ORP Meter made by HANNA instruments) at $20 \mathrm{~min}$ interval, and titrating carboxylic groups released with $1 \mathrm{mM} \mathrm{NaOH}$. The reaction mixture $(6 \mathrm{~mL})$ contained $1 \%$ orange pectin, $\mathrm{pH}$ adjusted to 7.0 without $\mathrm{pH}$ buffer and a volume of $3 \mathrm{~mL}$ of crude extract. The control was realized in the same conditions as the assay but contained heated crude enzymes extract. Reactions were performed at $30^{\circ} \mathrm{C}$ for $1 \mathrm{~h}$. The volume of $1 \mathrm{mM} \mathrm{NaOH}$ use to assay the acidity produce during enzymatic reaction constitutes enzyme activity $(\mathrm{U})$ and enzyme production is defined as units of enzyme activity (U) per $\mathrm{mL}$ of supernatant.

\subsubsection{Effects of fermentative Conditions on Pectinase Production in Yeasts Studied}

The influence of different stress conditions on the production of pectinases was carried out by the method described in the pectinase production in liquid medium (Dzobgefia et al., 2008). Liquid medium 1\% pectin; $0.28 \%\left(\mathrm{NH}_{4}\right)_{2} \mathrm{SO}_{4} ; 0.1 \% \mathrm{KH}_{2} \mathrm{PO}_{4} ; 0.05 \% \mathrm{MgSO}_{4} .7 \mathrm{H}_{2} \mathrm{O} ; 0.001 \% \mathrm{FeSO}_{4} .7 \mathrm{H}_{2} \mathrm{O} ; 0.6 \% \mathrm{~K}_{2} \mathrm{HPO}_{4}$ and adjusted to $\mathrm{pH} 5.0$ was used. To this medium, different stress factors to be tested were added at various concentrations. Glucose and fructose ( 1 to $8 \%$ ) were used to test osmotic stress on enzymes production. Acid stress was achieved by using acetic acid, lactic acid and citric acid at concentrations ranging respectively from 0.25 to $0.75 \%, 1$ to $2 \%$ and 2 to $6 \%$. Alcoholic stress effect on enzymes production was tested with ethanol at concentrations from 2 to $12 \%$. Effects of temperature and $\mathrm{pH}$ on enzymes production were carried out by using the same medium respectively at different $\mathrm{pH}$ ( 3 to 8 ) and at different temperatures ( 30 to $40{ }^{\circ} \mathrm{C}$ ).

\subsection{Statistical Analysis}

All the experiments were triplicate and Analysis of variance (ANOVA) was carried out with SPSS Statistics version 17.0. Software. Means comparison was performed using Duncan test at $95 \%$ level of confidence.

\section{Results}

\subsection{Carbohydrates Metabolism}

Regarding gas production in Durham tube at $30{ }^{\circ} \mathrm{C}$, the yeasts pectinolytic strains analyzed, presented a poor carbon metabolism profile with the ability to ferment only glucose and fructose as carbohydrate. These strains were not able to ferment even the sucrose. However, maximum growth of strains up to $\mathrm{OD}_{600}=0.50$ was obtained after $120 \mathrm{~h}$ incubation with $5 \%$ of glucose or fructose. Furthermore, the yeast growth at $5 \%$ of glucose concentration, proved to be generally stable with increasing temperature up to $40{ }^{\circ} \mathrm{C}$ (Table 1). The same observation was carried out with fructose for strains YS 128 and YS 202. In contrast, the growth of strains YS 165 and YS 201 at $5 \%$ fructose concentration was not stable beyond $30{ }^{\circ} \mathrm{C}$ since a notable decrease of relative growth rate was observed (Table 1).

\subsection{Effect of Osmotic Stress Induced By Glucose and Fructose on Yeasts Growth}

At sugar concentration ranging 5 to $15 \%$ at $30{ }^{\circ} \mathrm{C}$, the microbial growth is still elevated with nearly $80 \%$ of relative growth (Figure 1). Moreover, at glucose concentration more than $25 \%$, the relative growth dropped to less than $65 \%$. The yeasts growth is severely hindered when glucose concentration reach $30 \%$ corresponding to a relative growth rate of $33 \%$. These strains failed to grow at $40 \%$ of glucose or fructose concentration. Results also show that, the decrease of yeast growth due to high sugar concentration is sharper with glucose than with fructose (Figure 1). 
A

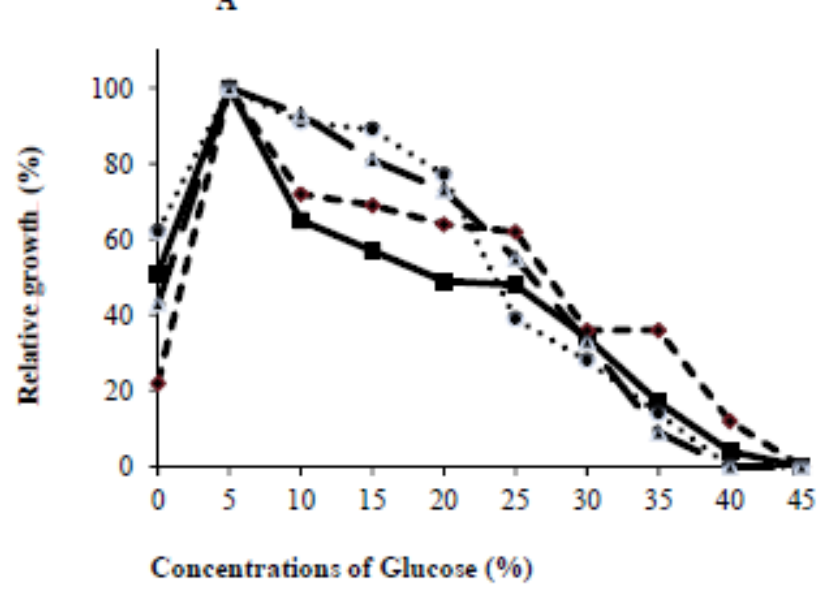

B

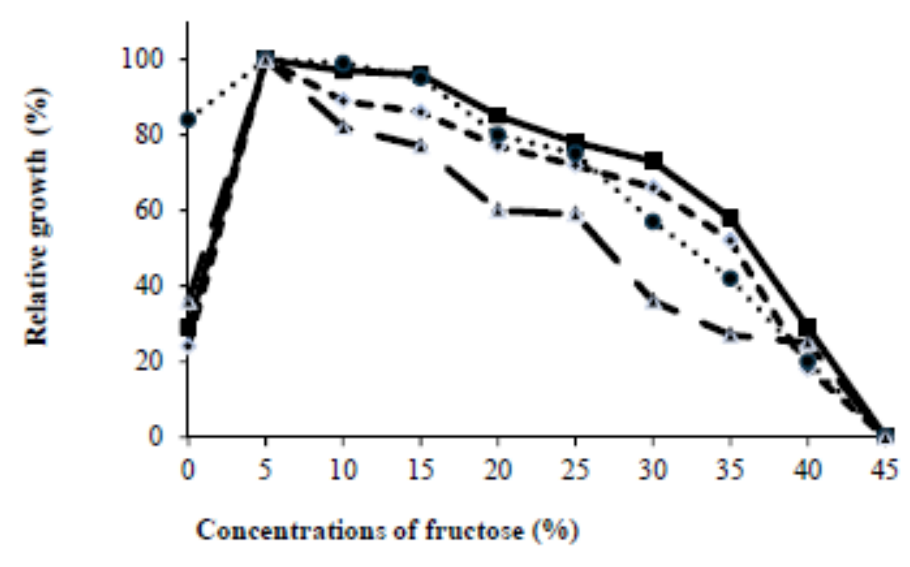

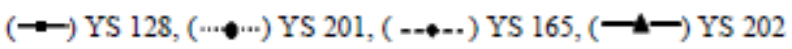

Figure 1. Influence of glucose (A) and fructose (B) on growth of pectinolytic yeast isolates. The pectinolytic yeasts were grew in Yeast-peptone-dextrose broth $(0.05 \%$ yeast extract, $0.3 \%$ Casein peptone) supplemented with sugar (glucose or fructose) at different concentrations and the medium was then incubated at $30^{\circ} \mathrm{C}$ for 5 days. Absorbance $\left(\mathrm{OD}_{600}\right)$ was used to measure yeast growth. Relative growth was expressed in percentage using the highest $\mathrm{OD}_{600}$ as $100 \%$ 
Table 1 . Growth capacity of yeast strains at $5 \%$ glucose and fructose at various temperatures

\begin{tabular}{ccccccc}
\hline & \multicolumn{2}{c}{ Absorbance $(600 \mathrm{~nm})$} \\
& \multicolumn{2}{c}{$30^{\circ} \mathrm{C}$} & \multicolumn{2}{c}{$35^{\circ} \mathrm{C}$} & \multicolumn{2}{c}{$40^{\circ} \mathrm{C}$} \\
\hline Yeast-strains & Glucose & Fructose & Glucose & Fructose & Glucose & Fructose \\
\hline YS 128 & $1.15 \pm 0.04^{\mathrm{a}}$ & $0.91 \pm 0.02^{\mathrm{c}}$ & $1.03 \pm 0.00^{\mathrm{b}}$ & $1.03 \pm 0.00^{\mathrm{b}}$ & $1.06 \pm 0.08^{\mathrm{ab}}$ & $1.01 \pm 0.01^{\mathrm{b}}$ \\
YS 165 & $1.20 \pm 0.03^{\mathrm{a}}$ & $0.99 \pm 0.04^{\mathrm{a}}$ & $1.32 \pm 0.00^{\mathrm{a}}$ & $0.82 \pm 0.01^{\mathrm{b}}$ & $1.22 \pm 0.04^{\mathrm{a}}$ & $0.59 \pm 0.00^{\mathrm{c}}$ \\
YS 201 & $0.99 \pm 0.07^{\mathrm{a}}$ & $0.77 \pm 0.02^{\mathrm{a}}$ & $1.02 \pm 0.03^{\mathrm{a}}$ & $0.78 \pm 0.01^{\mathrm{a}}$ & $0.84 \pm 0.04^{\mathrm{b}}$ & $0.68 \pm 0.02^{\mathrm{b}}$ \\
YS 202 & $1.12 \pm 0.00^{\mathrm{a}}$ & $0.78 \pm 0.02^{\mathrm{b}}$ & $1.14 \pm 0.01^{\mathrm{a}}$ & $0.84 \pm 0.03^{\mathrm{a}}$ & $1.09 \pm 0.03^{\mathrm{ab}}$ & $1.09 \pm 0.03^{\mathrm{ab}}$ \\
\hline
\end{tabular}

*Means with different letters in a line within each independent variable are significantly different $(\mathrm{p}<0.05)$ for that independent variable at $\mathrm{p}<0.05$.

\subsection{Influence of Temperature on Fermentative Capacity of Yeast Strains Studied}

Yeasts are generally characterized by their ability to oxidize sugar notably glucose into ethanol with gas production. Since ethanol and gas $\left(\mathrm{CO}_{2}\right)$ are produced in equal number of moles, the quantity of ethanol or gas produced assess the fermentation power of strains. The results indicated that pectinolytic strains studied present the higher gas production at $35{ }^{\circ} \mathrm{C}$. The strain YS 202 presented the most important gas production corresponding to a volume of $10.78 \mathrm{~cm}^{3}$. This production is 2-folds higher than that yielded by the weaker gas producer (strain YS 128) (Figure 2). At $40{ }^{\circ} \mathrm{C}$, the strains lost more than $50 \%$ of their fermentative capacity.

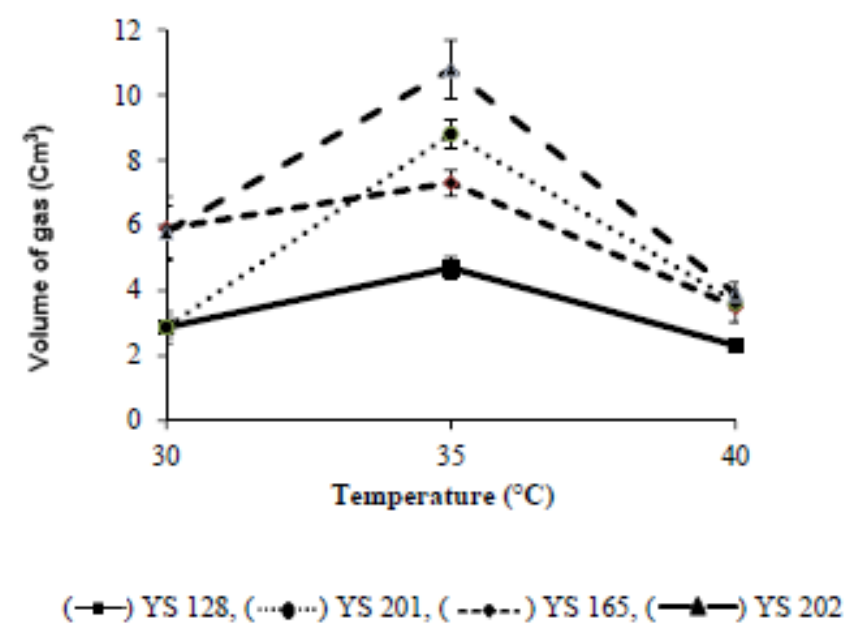

Figure 2. Fermentative capacity of pectinolytic yeast isolates at various temperatures. Pectinolytic strains were grew in the tube with double layer technique with YPG agar medium containing $0.05 \%$ yeast extract, $0.3 \%$ casein peptone, $5 \%$ glucose and $1.7 \%$ agar, pH5. Then, the medium was incubated at $30{ }^{\circ} \mathrm{C}, 35^{\circ} \mathrm{C}$ and $40{ }^{\circ} \mathrm{C}$ for 5 days and after incubation time the volume of gas in tube was measured and calculated

\subsection{Influence of Temperature and pH on Production of Polygalacturonase by Yeast Isolates}

The yeast strains analyzed produced only polygalacturonase as pectinolytic enzyme. The strain YS 202 displaying the most important gas production presented also the best enzyme production with $3.75 \mathrm{U} . \mathrm{mL}^{-1}$ of supernatant. Maximum polygalacturonase production occurred at $30{ }^{\circ} \mathrm{C}$ in strains YS165 and YS201 followed by a strong reduction of enzymatic synthesis at $35^{\circ} \mathrm{C}$ and $40{ }^{\circ} \mathrm{C}$ (Figure 3). In contrast, strains YS 128 and YS 202 , showed maximum enzymatic yield at $35^{\circ} \mathrm{C}$, and enzymes production in these strains, varied very less with different temperatures $\left(30\right.$ to $40{ }^{\circ} \mathrm{C}$ ) since $80 \%$ of enzymes production was conserved at these temperatures. Hence, the production of polygalacturonase seems to be stable in the strains YS 128 and Y S202.

On the other hand, isolates YS 128 and YS 202 gave an optimal production of polygalacturonase at initial pH 5.0, and lost their capacity of enzyme synthesis at pH 7.0. Likewise, the strains YS 165 and YS 201 yielded 
maximum polygalacturonase at initial $\mathrm{pH} 6.0$ but failed to produce this enzyme at $\mathrm{pH}$ 8.0. Among the isolates tested, only YS 201 was able to produce polygalacturonase at $\mathrm{pH} 3.0$ and this strain presented also the widest $\mathrm{pH}$ range of enzymes production (Figure 4).

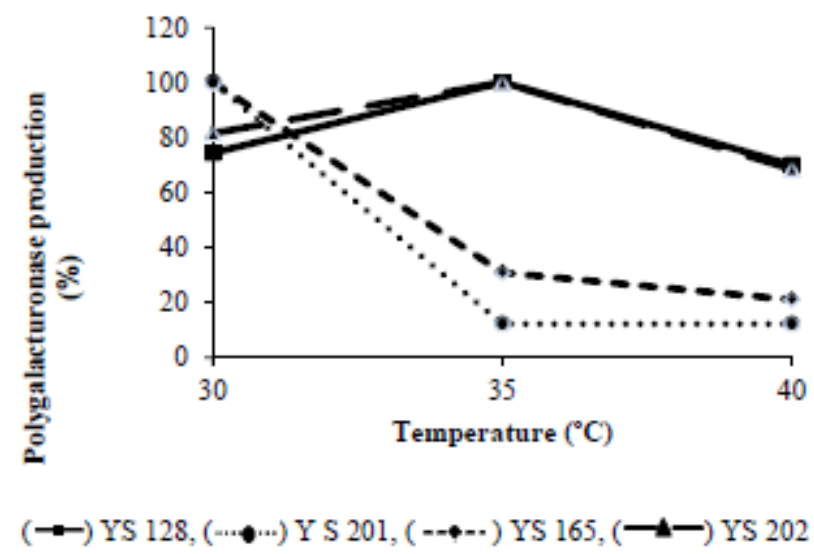

Figure 3. Influence of temperature on production of polygalacturonase by yeast isolates pectinolytic. The isolates were cultivated in a medium containing $1 \%$ pectin; $0.28 \%\left(\mathrm{NH}_{4}\right)_{2} \mathrm{SO}_{4} ; 0.1 \% \mathrm{KH}_{2} \mathrm{PO}_{4} ; 0.05 \% \mathrm{MgSO}_{4} .7 \mathrm{H}_{2} \mathrm{O} ; 0.001 \%$

$\mathrm{FeSO}_{4} .7 \mathrm{H}_{2} \mathrm{O} ; 0.6 \% \mathrm{~K}_{2} \mathrm{HPO}_{4}$ and adjusted to $\mathrm{pH}$ of 5.0 and incubated at different temperatures for 5 days

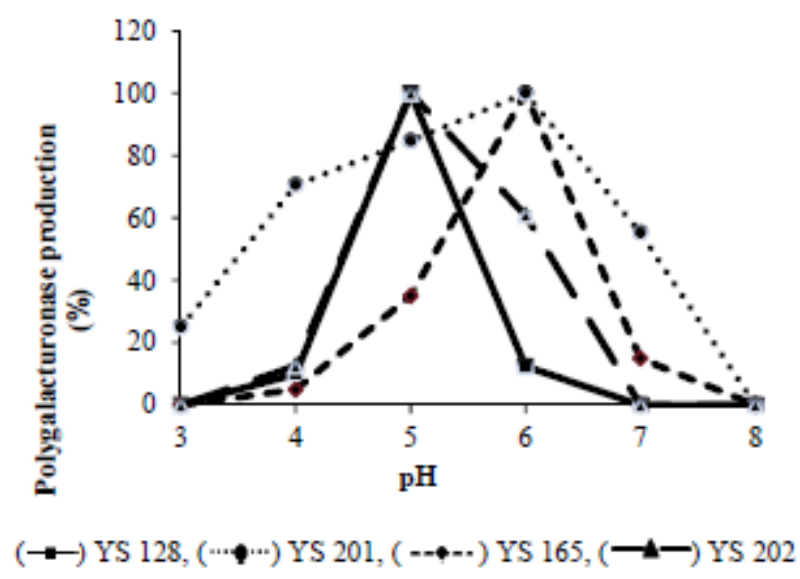

Figure 4. Influence of $\mathrm{pH}$ on production of polygalacturonase by yeast isolates pectinolytic. The isolates were cultivated in a medium containing $1 \%$ pectin; $0.28 \%\left(\mathrm{NH}_{4}\right)_{2} \mathrm{SO}_{4} ; 0.1 \% \mathrm{KH}_{2} \mathrm{PO}_{4} ; 0.05 \% \mathrm{MgSO}_{4} .7 \mathrm{H}_{2} \mathrm{O} ; 0.001 \%$ $\mathrm{FeSO}_{4} .7 \mathrm{H}_{2} \mathrm{O} ; 0.6 \% \mathrm{~K}_{2} \mathrm{HPO}_{4}$ and adjusted at different $\mathrm{pH}$ and incubated at $30{ }^{\circ} \mathrm{C}$ for 5 days

\subsection{Influence of Alcoholic, Osmotic and Acid Stress on Polygalacturonase Production by Yeasts Isolates}

In general, the production of polygalacturonase in yeast strains YS 128, YS 165 and YS 202 decrease progressively with increasing concentration of different stress factors (Table 2). Enzymes production is strongly repressed at $4 \%$ of glucose and at $8 \%$ of this sugar, the strains failed to produce polygalacturonase. Fructose had similar effect as glucose. Moreover, the acids tested also provoked the lowering of enzymes production in yeasts studied. Acetic acid revealed to have the most severe negative action on polygalacturonase production. At only $0.5 \%$ of this acid, the production was null while the failure of enzymes production is observed with $2 \%$ lactic acid, $6 \%$ citric acid and $6 \%$ ethanol (Table 2 ).

However, particularly in yeast strain YS 201, glucose at $1 \%$ and lactic acid at $1 \%$ seem to stimulate the production of polygalacturonase (Table 2). Beyond these concentrations, the repressive action of stress factors was also observed like the other strains. The suppression of enzymes production due to the different stress factors studied is materialized by the disappearance of the clear halo around the wells (Figure 5). 


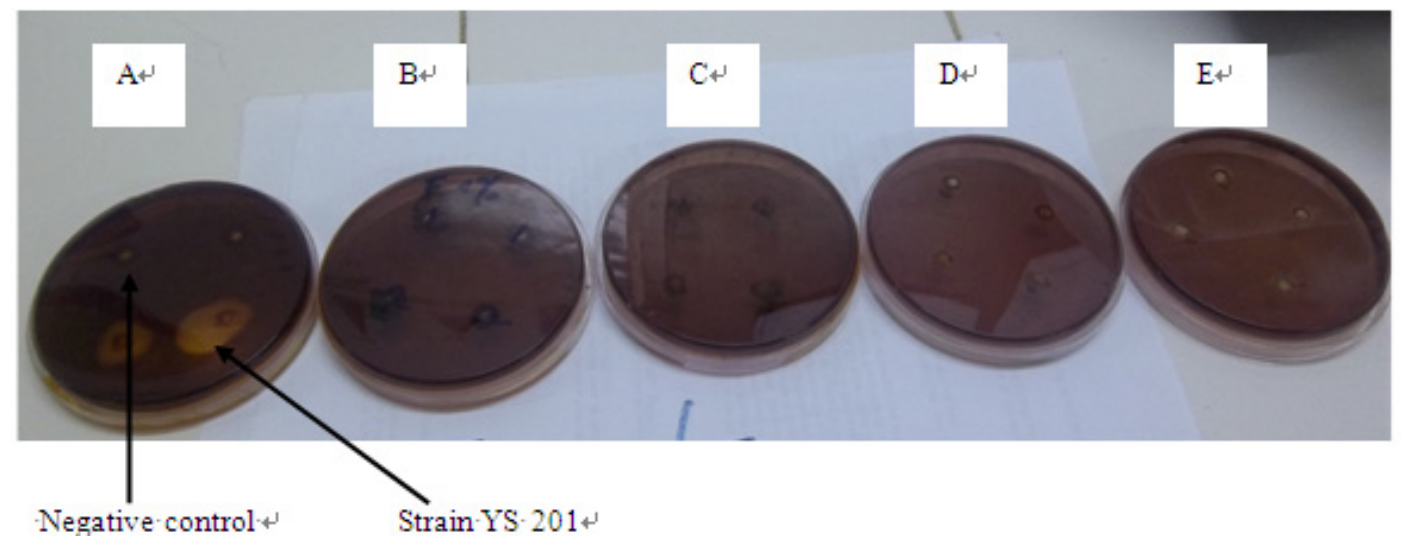

Figure 5. Illustration of suppressive action of stress factor on pectinolytic enzymes production in yeast strain YS 201. Plate A contained the basal medium (1\% pectin; $0.28 \%\left(\mathrm{NH}_{4}\right)_{2} \mathrm{SO}_{4} ; 0.1 \% \mathrm{KH}_{2} \mathrm{PO}_{4} ; 0.05 \% \mathrm{MgSO}_{4} .7 \mathrm{H}_{2} \mathrm{O}$; $0.001 \% \mathrm{FeSO}_{4} .7 \mathrm{H}_{2} \mathrm{O} ; 0.6 \% \mathrm{~K}_{2} \mathrm{HPO}_{4}, 1.7 \%$ agar and adjusted to $\mathrm{pH} 5.0$ ); the other plates contained the basal medium plus the stress factor. Plate B $8 \%$ glucose, plate C $0.5 \%$ acetic acid, plate D $2 \%$ lactic acid, plate E $6 \%$ ethanol. For each plate two wells are seeded with a yeast strain non producer of pectinolytic enzyme (negative control, from our laboratory collection) and the two others wells are seeded with the strain YS 201

Table 2. Effect of alcoholic, osmotic and acid stress on polygalacturonase production by yeast isolates

\begin{tabular}{|c|c|c|c|c|c|c|c|c|c|c|c|}
\hline \multicolumn{12}{|c|}{ Polygalacturonase production (U/ml of supernatant) } \\
\hline \multirow{2}{*}{$\begin{array}{c}\text { Yeast } \\
\text { Strains }\end{array}$} & \multirow{2}{*}{$\begin{array}{c}\text { Medium } \\
\text { without stress } \\
\text { factor }\end{array}$} & \multicolumn{3}{|c|}{ Glucose (\%) } & \multirow{2}{*}{$\begin{array}{c}\begin{array}{c}\text { Acetic } \\
\text { acid }(\%)\end{array} \\
0.25\end{array}$} & \multicolumn{2}{|c|}{ Lactic acid (\%) } & \multicolumn{2}{|c|}{ Citric acid (\%) } & \multicolumn{2}{|c|}{ Ethanol (\%) } \\
\hline & & 1.0 & 2.0 & 40 & & 1.0 & 2.0 & 2.0 & 4.0 & 2.0 & 4.0 \\
\hline YS 128 & $1.9 \pm 0.1^{\mathrm{a}}$ & $0.9 \pm 0.0^{\mathrm{b}}$ & $0.0 \pm 0.0^{\mathrm{c}}$ & $0.0 \pm 0.0^{\mathrm{c}}$ & $0.0 \pm 0.0^{\mathrm{c}}$ & $0.0 \pm 0.0^{\mathrm{c}}$ & $0.0 \pm 0.0^{\mathrm{c}}$ & $0.0 \pm 0.0^{\mathrm{c}}$ & $0.0 \pm 0.0^{\mathrm{c}}$ & $0.45 \pm 0.1^{\mathrm{c}}$ & $0.45 \pm 0.1^{\mathrm{c}}$ \\
\hline YS 165 & $2.7 \pm 0.2^{\mathrm{a}}$ & $0.9 \pm 0.1^{\mathrm{c}}$ & $0.0 \pm 0.0^{\mathrm{d}}$ & $0.0 \pm 0.0^{\mathrm{d}}$ & $0.0 \pm 0.0^{\mathrm{d}}$ & $0.0 \pm 0.0^{\mathrm{d}}$ & $0.0 \pm 0.0^{\mathrm{d}}$ & $0.3 \pm 0.0^{\mathrm{bc}}$ & $0.0 \pm 0.0^{\mathrm{d}}$ & $1.2 \pm 0.1^{\mathrm{b}}$ & $0.0 \pm 0.0^{\mathrm{d}}$ \\
\hline YS 201 & $4.4 \pm 0.2^{\mathrm{a}}$ & $2.4 \pm 0.3^{\mathrm{b}}$ & $1.1 \pm 0.1^{\mathrm{cd}}$ & $0.5 \pm 0.0^{\mathrm{d}}$ & $0.9 \pm 0.3^{\mathrm{d}}$ & $2.0 \pm 0.2^{\mathrm{bc}}$ & $0.0 \pm 0.0^{\mathrm{d}}$ & $4.0 \pm 0.5^{\mathrm{a}}$ & $0.18 \pm 0.1^{\mathrm{b}}$ & $2.2 \pm 0.6^{b}$ & $0.07 \pm 0.0^{\mathrm{d}}$ \\
\hline YS 202 & $4.4 \pm 0.2^{\mathrm{b}}$ & $8.0 \pm 0.1^{\mathrm{a}}$ & $0.3 \pm 0.0^{\mathrm{f}}$ & $0.0 \pm 0.0^{\mathrm{f}}$ & $2.0 \pm 0.7^{\mathrm{e}}$ & $7.6 \pm 0.1^{\mathrm{a}}$ & $4.7 \pm 0.0^{\mathrm{c}}$ & $5.1 \pm 0.1^{\mathrm{bc}}$ & $2.2 \pm 0.2^{\mathrm{e}}$ & $3.4 \pm 0.3^{\mathrm{d}}$ & $2.2 \pm 0.4^{\mathrm{e}}$ \\
\hline
\end{tabular}

* Means with different letters in a line within each independent variable are significantly different $(\mathrm{p}<0.05)$ for that independent variable at $\mathrm{p}<0.05$.

\section{Discussion}

Yeast strains presenting interesting properties notably pectinolytic enzymes production and stress resistance previously isolated from cocoa fermenting bean have been analyzed in this study by several approaches. First, their carbon metabolism was analyzed. The strains presented a narrow carbon metabolism profile with the capacity to ferment only glucose and fructose among the carbohydrates tested. It is known that, yeasts present one of the wide microbial diversity in which strains can behave very differently depending on their intrinsic properties but also on environmental conditions (Berthels et al., 2004). For instance, among yeast strains previously isolated from brewed beverages, Candida magnolia was found to ferment glucose and sucrose whereas Saccharomyces cereviciae was able to ferment other sugars such as galactose, sucrose, raffinose and maltose (Jimoh et al., 2012). This difference in carbon metabolism is due to the transport system associated to the membrane which exerts selection of carbohydrate to enter into the yeast cells (Perez et al., 2005; Guillaume et al., 2007). The best suited carbohydrates for the transport system should be preferentially metabolized. Generally, the pulp constituting the substrate of cocoa fermentation contains mainly glucose and fructose which are to be fermented into ethanol and at term, into acetic acid (Schwan \& Wheals, 2004). These reactions are essential for specific flavor and aroma of the cocoa beans and chocolate (Rohsius et al., 2009). From this point of view, although their restricted carbon metabolism, the yeast strains studied should keep entirely their use as valuable strains to ferment cocoa beans. 
Maximum growth of strains studied occurred at $5 \%$ of glucose and fructose concentration and beyond this concentration, the biomass is reduced. Similar results were also obtained by authors reporting that Saccharomyces cerevesiae gave a good growth with glucose at 5\% (Larpent \& larpent, 1997). The reduction of yeasts biomass at increasing concentration of sugars should be due to a catabolic repression exerted by glucose on enzymes involved in glycolysis (Larpent \& Larpent, 1997, Sriban, 1999). The total concentration of glucose and fructose present in the cocoa pulp round 10-13\% (Roelofsen, 1958; Schwan \& Wheals, 2004) is susceptible to induce not only catabolite repression but also osmotic pressure in the fermenting bean and to subsequently hinder microbial growth. The results show that yeast strains studied conserved more than $80 \%$ of their relative growth at $15 \%$ of glucose concentration indicating that these strains should be widely able to adapt to osmotic stress during cocoa fermentation.

The fermentation capacity of yeast strains was also tested at different temperatures by measuring the volume of gas yielded. It appears that, all the strains analyzed produce larger amount of gas (carbon dioxide) from glucose at $35{ }^{\circ} \mathrm{C}$, some producing more gas than others. This is not surprising since we have observed that maximum growth of yeast is also achieved at this temperature (Samagaci et al., 2014). It is common that maximum activity of yeast occur in the temperature range $30-35{ }^{\circ} \mathrm{C}$ (Banu et al., 2011; Dung et al., 2012). Generally, the temperature of the fermenting cocoa mass reaches $35^{\circ} \mathrm{C}$ in the first 24 hours of fermentation. This period may correspond to the highest fermentative activity and the most important ethanol production from yeast strains. However, at $40{ }^{\circ} \mathrm{C}$ the strains lost more than $50 \%$ of their fermentative capacity corresponding generally to $48 \mathrm{~h}$ of fermentation (Pereira et al. 2013). This may help to give an accurate insight into the timing of yeasts activity in cocoa fermentation. As the production of ethanol is useful for improvement of cocoa beans quality (Barel, 1997) the strain YS 202 displaying the most important fermentative capacity may be a valuable starter.

Furthermore, the yeast strains analyzed produced only polygalacturonase as pectinolytic enzymes. Likewise, Schwan et al. (1997) reported that yeast strains from Brazilian cocoa fermentation produced only polygalacturonase. It has been also reported that, yeasts involved in wine, coffee and olive fermentation were not able to produce others pectinolytic enzymes than polygalacturonase (Blanco et al., 1994, Guessous et al., 2000). It seems that yeasts produce more generally, polygalacturonase. However, Gummadi and Kumar (2008) showed that the Debaryomyces nepalensis iolated from rotten apple in Indian produces pectate lyase and pectin lyase. For improvement of cocoa fermentation purposes, an efficient pectinolytic activity of the isolates tested, should rely on their combination with others pectinolytic strains such as Bacillus which are able to produce others types of pectinolytic enzymes, like pectate lyase and pectin methyl-esterase to (Ouattarra et al., 2008).

Results also showed that enzymes production of isolates ranged between $0.88 \pm 0.04$ and $3.75 \pm 0.41 \mathrm{U} / \mathrm{mL}$. This level of enzymatic production is higher than that reported by Bekhouche (2006) who have found a production level ranging between $0.01-0.44 \mathrm{U} / \mathrm{mL}$ with yeast strains of genus Candida sp, Cryptococus sp, Rhizopus sp and Rhodotorula $s p$ isolated from fermenting olives in Algeria. However, the level of polygalacturonase production in isolates tested is below that yielded by Bacillus licheniformis isolated from fermenting mashed potatoes in India which was $4 \mathrm{U} / \mathrm{mL}$ (Preeti \& Ashok, 2013). Pulp degrading enzymes are known to have a significant impact on cocoa fermented products (Schwan \& Wheals, 2004) and the strain YS 202 appears to have the most important potential of enzymes production during cocoa fermentation.

The maximum enzyme productions occur at $30^{\circ} \mathrm{C}$ for strains YS 128 , YS 202 and $35^{\circ} \mathrm{C}$ for strains YS 165 and YS 201. The range of temperature for enzymes production in yeasts studied is the same as that for fermentative activity, assessing that this interval of temperature correspond the optimum physiological activity of the strains studied. On the other hand, the optimal $\mathrm{pH}$ of polygalacturonase production is $\mathrm{pH} 5.0$ for strains YS 128, YS 202 and $\mathrm{pH} 6.0$ for strains YS 165, YS 201. Previously, yeast strains from Brazilian cocoa fermenting beans were also found to produce polygalacturonase at $\mathrm{pH}$ ranging between 4.0 and 6.0 (Sanchez et al., 1985; Schwan et al., 1997). The yeast strains isolated from Ivorian fermenting beans having different optimums $\mathrm{pH}$ for polygalacturonase production offer a possibility for maximum exploitation of their potential. In fact, the $\mathrm{pH}$ of the fermenting cocoa varies from 3.0 at the beginning of fermentation to reach $\mathrm{pH} 8.0$ at the end (Guehi et al. 2010). So, the use of these isolates as mixed starter should allow a constant production of polygalacturonase during cocoa fermentation.

One of the notable features of the yeast strains analyzed is their sensitivity to environmental stress for polygalacturonase synthesis. The glucose and fructose at $1 \%$, ethanol at $2 \%$, acetic acid at $0.25 \%$, lactic acid at $1 \%$ and citric acid at $2 \%$ repressed strongly the production of polygalacturonase. Such observation has been reported by Oliviera et al. (2005) with Saccharomyces sp isolated from the lemon molasses in fermentation in which the polygalacturonase was suppressed by glucose, whereas repression of this enzymes by acid or ethanol have rarely been reported. Such conditions prevailing in cocoa fermentation may prevent the production of 
pectinolytic enzymes in yeasts studied. However, the course of cocoa fermentation imposes a continuous changing and dynamic of fermentative conditions. Hence, the stress conditions leading to the drop of polygalacturonase should be transient. Although certain conditions occurring in cocoa fermentation are susceptible to hinder the synthesis of polygalacturonase, it is regularly reported that yeast strains are involved in pectinolytic enzyme production during fermentative process (Schwan \& Wheals, 2004). Procedures for an efficient use of microbial starter strains, should take into account these conditions.

\section{Conclusion}

Yeasts strains studied showed strong fermentative capacity with glucose and fructose as substrate. Additionally these strains are able to grow and keep this property at temperature up to $40{ }^{\circ} \mathrm{C}$. These strains showed a strong resistance to osmotic stress and grow relatively well under acid and alcoholic conditions. Polygalacturonase as pectinolytic enzyme, is the sole enzyme produced by yeast strains analyzed. This enzyme is maximally produced at temperature ranging in $30-35{ }^{\circ} \mathrm{C}$ at acidic $\mathrm{pH}$. Yeast isolates analyzed present some interesting physiological properties susceptible to make them, valuable starter (strains YS 202 for instance) for cocoa fermentation improvement. However, the suppression of polygalacturonase production by carbon substrate might hinder strongly the capacity of the isolates to ferment correctly cocoa beans.

\section{Acknowlegment}

This research was supported by the International Foundation for Science (IFS), Sweden, under grant E/4411-2.

\section{References}

Albertshein, P. (1966). Pectin lyase from fungi. Methods in Enzymology, 8, 628-631. http://dx.doi.org/10.1016/0076-6879(66)08113-8

Banu, I., Vasilean, I., \& Aprodu, I. (2011). Effect of Select Parameters of the Sourdough Rye Fermentation on the Activity of Some Mixed Starter Cultures. Food Biotechnology, 25(4), 275-291. http://dx.doi.org/10.1080/08905436.2011.617251

Barel, M. (1997). La Fermentation de Cacao, in Microbiologie Alimentaire Tome 2 C.M. Bourgeois, J-P. Larpent, Coordonnateurs Tec et Doc Lavoisier, p. 664.

Bhumibhamon, O., \& Jinda, J. (1997). Effect of enzymes pectinases on natural cocoa fermentation. Kasetsart J. Nat. Sci., 31, 206-212.

Bekhouche, F. (2006). Bactéries lactiques du lait cru de vache et Microorganismes pectinolytiques des olives noires et vertes : 1. Isolement et Identification biochimique. 2. Evaluation et Optimisation de la production d'enzyme polygalacturonase. Thèse, Institut de la nutrition de l'alimentation et des technologies agroalimentaires, Algérie, p. 149.

Blanco, P., Sieiro, C., Diaz, A., \& Villa, T. G. (1994). Production and partial characterization of an endopolygalacturonase from Saccharomyces cereviciae. Canadian Journal of Microbiology, 40(11), 974-977. http://dx.doi.org/10.1139/m94-155

Berthels, N. J., Cordero, O. R. R., Bauer, F. F., Thevelein, J. M., \& Pretorius, I. S. (2004). Discrepancy in glucose and fructose utilization during fermentation by Saccharomyces cerevisiae wine yeast strains. FEMS Yeast Research, 4, 683-689. http://dx.doi.org/10.1016/j.femsyr.2004.02.005

Biehl, B., \& Voigt, J. (1996). Biochemistry of cocoa flavor precursors. Proceeding in the 12th International Cocoa Research Conference, Salvador Brazil, Lagos Nigeria: Cocoa producers' alliance, pp. 929-938.

Crafack, M., Mikkelsen, M., Saerens, S., Kundsen, M., Blenbow, A., Lowor, S., ... Nielsen, D. N. (2013). Influencing cocoa flavor using Pichia Klutveri and Kluyveromyces marxianus in a defined starter culture for cocoa fermentation. International Journal of Food Microbiology, 167, 103-116. http://dx.doi.org/10.1016/j.ijfoodmicro.2013.06.024

Dung, N. T. P., Pornthap T., \& Huynh, X. P. (2012). Screening Useful Isolated Yeasts for Ethanol Fermentation at High Temperature. International Journal of Applied Science \&Technology, 4, 65-71.

Dzogbefia, V. P., Ofosu, G. A., \& Oldham, J. H. (2008). Evaluation of locally produced Saccharomyces cerevisiae pectinase enzyme for industrial extraction of starch from cassava in Ghana. Scientific Research \& Essay, 3(8), 365-369.

Guehi, T. S., Konan, Y. M., Koffi-Nevry, R., N'dri, D. Y., \& Manizan, N. P. (2010). Enumeration and identification of main fungal isolates and evaluation of fermentation's degree of Ivorian raw cocoa beans. Autsralian Journal of. Basic \& Applied Science, 1(4), 479-486. 
Guessous, Z., Ouhssine, M., Mokhtari, A., Faid, M., \& Yachioui, M. (2000). Isolement et caractérisation de Geotricum candidum pour la production d'une polygalacturonase extracellulaire. Science des Aliments, 20(3), 309-320. http://dx.doi.org/10.3166/sda.20.309-320

Gummadi, S. N., \& Kumar, D. S. (2008). Batch and fed batch production of pectin lyase and pectate lyase by novel strain Debaryomyces nepalensis in bioreactor. Bioresource Technology, 99, 874-881. http://dx.doi.org/10.1016/j.biortech.2007.01.022

Hesclot, H., \& Vladescu, B. (1994). La levure dans les industries alimentaires Ed. Tec \& Doc, Lavoisier, p. 56.

Ho, V., Zhao, J., \& Fleet, G. (2014). Are yeast essential for cocoa bean fermentation. International Journal of Food Microbiology, 174, 72-87. http://dx.doi.org/10.1016/j.ijfoodmicro.2013.12.014

Holm, C. S., Aston, J. W., \& Douglas, K. (1993). The effects of the organic acids in cocoa on flavor of chocolate. Journal of the Science of Food \& Agriculture, 61, 65-71. http://dx.doi.org/10.1002/jsfa.2740610111

Jimoh, S. O., Ado, S. A., Ameh, J. B., \& Whong C. M. (2012). Osmotolerance and Fermentative Pattern of Brewer's Yeast. World Journal of Life Science \& Medical Research, 2(2), 59-64.

Larpent, J. P., \& Larpent, G. M. (1997). Mémento technique de microbiologie. (3rd édition), Lavoisier-Tec \&Doc, Paris, p. 23.

Leal, G. A., Gomes, L. H., Efraim, Tavares, F. C. A., \& Figueira, A. (2008). Fermentation of cacao (Theobroma cacao L.) seeds with a hybrid Kluyveromyces marxianus strain improved product quality attributes. FEMS Yeast Research, 8, 788-798. http://dx.doi.org/10.1111/j.1567-1364.2008.00405.x

Lopez, A. S., \& Dimick P. S. (1995). Cocoa fermentation. In G. Reed \& T. W.Nagodawithana (Eds.), Enzymes, Biomass, Food and Feed. VCH, Weinheim, pp. 561-577.

Miller, G. L. (1959). Use of dinitrosalicylic acid reagent for determination of reducing sugars. Analytical Chemistry, 31, 426-428. http://dx.doi.org/10.1021/ac60147a030

Nielsen, D. S. (2006). The microbiology of Ghanaian cocoa fermentations. Thesis, Department of Food Science, the Royal Veterinary and Agricultural University Denmark, p. 111.

Oliveira, K. F., Malavolta, L., Souza, C. S., Vicente, E. J., \& Laluce, C. (2005). Pectinolytic activity secreted by yeasts isolated from fermented citrus molasses. Journal of Applied Microbiology, 100, 633-640. http://dx.doi.org/10.1111/j.1365-2672.2006.02823.x

Ouattara, H. G., Ban-Koffi, L., Karou, G. T., Sangare, A., Niamke, S. L., \& Diopoh, J. K. (2008). Implication of Bacillus sp. in the production of pectinolytic enzymes during cocoa fermentation. World Journal of Microbioogy \& Biotechnology, 24, 1753-1760. http://dx.doi.org/10.1007/s11274-008-9683-9

Ouattara, H. D., Ouattara G. H., Goualie, B. G., Kouame, L. M., \& Niamke, S. L. (2014). Biochemical and functional properties of lactic acid bacteria isolated from Ivorian cocoa fermenting beans. Journal of Applied Biosciences, 77, 6489-6499. http://dx.doi.org/10.4314/jab.v77i0.9

Osho, A. (2005). Ethanol and Sugar tolerance of wine yeasts isolated from fermenting cashew apple juice. African Journal of Biotechnology, 4(7), 660-662. http://dx.doi.org/10.5897/AJB2005.000-3119

Perez, M., Luyten, K., Michel, R., Riou, C., \& Blondin, B. (2005). Analysis of Saccharomyces cerevisiae hexose carrier expression during wine fermentation: both low- and high-affinity Hxt transporters are expressed. FEMS Yeast Research, 5, 351-361. http://dx.doi.org/10.1016/j.femsyr.2004.09.005

Pereira, G. V. M., Magalhães, K. T., Almeida, E. G., Coelho, I. S., \& Schwan R. F. (2013). Spontaneous cocoa bean fermentation carried out in a novel-design stainless steel tank: Influence on the dynamics of microbial populations and physical-chemical properties. International Journal of Food Microbiology, 161, 121-133. http://dx.doi.org/10.1016/j.ijfoodmicro.2012.11.018

Preeti, G. D., \& Ashok, V. G. (2013). Bacterial Polygalacturonase (PG) Production from Agro Industrial Waste by Solid State Fermentation. Indian journal of applied research, 3(6), 439-442.

Roelofsen, P. A. (1958). Fermentation, drying, and storage of cocoa beans. Advances in Food Research, 8, 225-296. http://dx.doi.org/10.1016/S0065-2628(08)60021-X

Rohsius, C., Andersson, M., Niemenak, N., Sukha, D., \& Lieberei, R. (2009). La qualité de la fermentation et ses rapports avec la structure de la Testa et les processus de transport. 15ème Conférence Internationale Sur La Recherche Cacaoyère Présenté par le Programme National Cacao de l'INIAP, équateur. 
Samagaci, L., Ouattara, H. G., Goualié, B. G., \& Niamke, S. L. (2014). Growth capacity of yeasts potential starter strains under cocoa fermentation stress conditions in Ivory Coast. Emirates Journal of Food \& Agriculture, 26(10), 861-870.

Sanchez, J., Daguenet, G., Guiraud, J. P.,Vincent, J. C., \& Galzy, P. (1985). A study of the yeast flora and the effect of pure culture seeding during the fermentation of cocoa beans. Lebensm. wiss. Technology, 18, 69-76.

Schwan, R. F., Cooper, R. M., \& Wheals A. E. (1997). Endopolygalacturonase secretion by Kluyveromyces marxianus and other cocoa pulp-degrading yeasts. Enzyme \& Microbial Technology, 21(4), 234-244. http://dx.doi.org/10.1016/S0141-0229(96)00261-X

Schwan, R. F., \& wheals, A. E. (2004). The microbiology of cocoa fermentation and its role in chocolate quality. Critical Reviews in Food Science \& Nutrition., 44, 204-221. http://dx.doi.org/10.1080/10408690490464104

Scriban, R. (1999). Biotechnologies (5th édition), Techniques et Documentation-Lavoisier, pp, 149-157.

Wickerham, L. J. (1951). Taxonomy of yeast. Technical Bulletin No. 1029, United States. Washington DC, Department of Agriculture.

Ziegleder, G. (1991). Composition of flavor extracts of raw and roasted beans. Lebensmitt Unters-Forsch, 192, $521-525$.

\section{Copyrights}

Copyright for this article is retained by the author(s), with first publication rights granted to the journal.

This is an open-access article distributed under the terms and conditions of the Creative Commons Attribution license (http://creativecommons.org/licenses/by/3.0/). 